\title{
PENYULUHAN PENCEGAHAN PENULARAN COVID-19 DAN PEMBAGIAN MASKER DI KECAMATAN PEDURUNGAN KOTA SEMARANG
}

\author{
Sri Maria Puji Lestari ${ }^{1 *}$, Hetti Rusmini ${ }^{2}$, Yesi Nurmalasari ${ }^{3}$, Maharani Putri \\ Puspitasari $^{4}$ \\ ${ }^{1,2,3,4}$ Fakultas Kedokteran Umum Universitas Malahayati \\ Email Koresnpondensi: srimariapujilestari@gmail.com
}

\begin{abstract}
ABSTRAK
Akhir tahun 2019 dunia dikejutkan adanya virus baru yaitu Covid-19. Pemerintah setempat telah mengambil langkah yang cukup cepat untuk pencegahan virus Covid19 dengan menetapkan beberapa gerakan melalui Sosialisai Social Distance. Bentuk sosialisai yang di lakukan dengan cara penyuluhan untuk selalu taat pada protokol kesehatan dan mengenakan masker saat memuali kegiatan di luar rumah yang masih sering diabaikan. Dari hasil pengamatan awal yang dilakukan pada beberapa tempat di Kecamatan Pedurungan Kota Semarang, sudah mulai banyak di jumpai café dan titik pertemuan masyarakat yang telah sadar atas pentingnya penggunaan masker untuk mencegah penyebaran Covid-19, Namun tak jarang juga masih ada yang bandel dengan tidak mengabaikan protokol kesehatan tersebut. Dikondisi seperti ini kita harus mampu menumbuhkan rasa kesadaran kepada seluruh masyarakat untuk taat dan patuh pada protokol kesehatan agar dapat menekan laju penyebaran Covid19 di Kecamatan Pedurungan Kota Semarang. Penyuluhan pada masyarakat diselenggarakan pada $1 \mathrm{~s} / \mathrm{d} 2$ Februari 2021 diselenggrakan dalam bentuk penyuluhan penggunaan masker sekaligus membagikan masker secara gratis kepada masyrakat di Kecamatan Pedurungan Kota Semarang. Metode yang di gunakan adalah melalui edukasi kepada beberapa masyarakat dengan menghimbau pentingnya menggunakan masker, kemudian pembagian masker. Penggunaan masker medis baik kain di kalangan masyarakat ini sangat penting karena termasuk kelompok yang rentan terpapar penyebaran Covid-19. Dengan mengenakan masker, masyrakat di Kecamatan Pedurungan Kota Semarang dapat beraktivitas dengan lebih nyaman.
\end{abstract}

Kata Kunci: Covid, Masker Menjaga jarak, Pandemi dan Penyuluhan

\begin{abstract}
The end of the year 2019 the world was shocked the presence of a new virus that is Covid-19. The local government has taken a step that's fast enough to virus prevention Covid-19 by setting some movement through the Socialization of Social Distance. A form of socialization that is done by way of extension to always obey the protocol of the health and wearing a mask when he started activities outside the home that are often overlooked. From the results of the preliminary observations made in several places in the District Pedurungan Semarang City, have started much in the encounter cafe and the meeting point of the community who have been aware
\end{abstract}


of the importance of the use of masks to prevent the spread of Covid-19, But not infrequently there are also a stubborn by not ignoring the protocols of the health. Situation like this we should be able to cultivate a sense of awareness to the entire community to be obedient and submissive to the protocol of the health order can reduce the rate of spread covid-19 in the District Pedurungan Semarang city. Outreach in the community was held on the $1 \mathrm{~s} / \mathrm{d} 2$ February 2021 text in the form of counseling, the use of masks at once distribute masks for free to the community in the District Pedurungan Semarang city The method used is through education to some of the community to urge the importance of using the mask, then the division of the mask. The use of medical masks good fabric among the people is very important because including vulnerable groups exposed to the spread of Covid-19. By wearing a mask, a community in the District Pedurungan Semarang City can move more comfortable.

Key Word: Covid, Masks, Keeping distance, Pandemic and outreach.

\section{PENDAHULUAN}

Coronavirus Disease 2019 (Covid-19) adalah penyakit jenis baru yang belum pernah diidentifikasi sebelumnya pada manusia. Virus penyebab Covid-19 ini dinamakan SarsCoV-2. Tanda dan gejala umum infeksi Covid-19 antara lain gejala gangguan pernapasan akut seperti demam, batuk dan sesak napas. Masa inkubasi rata-rata 5-6 hari dengan masa inkubasi terpanjang 14 hari.

Penyebaran virus corona jenis baru (SARS-Cov-2) di penghujung tahun 2019 yang kemudian diberi nama Covid-19 sangat menjadi perhatian dan kekhawatiran dunia. Covid-19 pertama kali ditemukan di kota Wuhan China yang kemudia bermigrasi dan mewabah ke seluruh dunia. Akibat dari penyebarannya yang cukup masiv tersebut pada akhirnya pada tanggal 11 Maret 2020 organisasi kesehatan dunia World Health Organizatin (WHO) menetapkan penyebacaran Covid 19 sebagai pandemi.

Pada kasus Covid-19 yang berat dapat menyebabkan pneumonia, sindrom pernapasan akut, gagal ginjal, dan bahkan kematian. Tanda-tanda dan gejala klinis yang dilaporkan pada sebagian besar kasus adalah demam, dengan beberapa kasus mengalami kesulitan bernapas, dan hasil rontgen menunjukkan infiltrat pneumonia luas di kedua paru (Kemenkes, 2020)

Kasus pertama di Indonesia yaitu pada warga Depok Jawa Barat. Keduanya diduga terpapar Covid-19 akibat kontak dengan warga negara Jepang yang datang ke Indonesia. Seiring dengan berjalannya waktu sehingga kasus terinfeksi Covid-19 terus bertambah.

Agar tidak terjadi penularan pemerintah Di Indonesia mengeluarkan kebijakan social distancing atau physical distancing (menjaga jarak) sehingga muaranya pda himbauan untuk stay at home (berdiam diri di rumah) dan lebih khusus di kota-kota yang sudah terdapat pasien Covid-19. konsep ini menjelaskan bahwa dapat mengurangi atau memutus mata rantai penularan atau penyebaran infeksi covid-19, dalam upaya ini seseorang harus menjaga jarak dengan orang lain minimal 1-2 meter, dan tidak melakukan kontak langsung dengan orang lain, menghindari kerumunan dan pertemuan masal (Ausrianti, dkk, 2020). 
Dalam rangka menindaklanjuti kebijan pemerintah tersebut, seluruh warung makan, tempat keramaian dan fasilitas umum menerapkan pembatasan pengunjung, jaga jarak antar pengunujung, pemakaian handsanitezer sebelum masuk ruangan, pengecekan suhu serta wajib memakai masker sebelum memasuki ruangan tersebut.

\section{MASALAH}

Berdasarkan hasil studi pengamatan pada tanggal 20 Januari 2021 didapatkan 727 kasus positif Covid19 di Kota Semarang, sedangkan di daerah Kecamatan Pedurungan menduduki peringkat pertama dengan total 90 kasus pasien positif Covid19 dari 16 Kecamatan. Karena masih banyak masyarakat yang kurang memperhatikan protokol kesehatan seperti kurangnya kedisiplinan mengenakan masker dengan benar dan masih banyak yang bandel untuk tidak mengenakan masker. Dalam kondisi pandemik saat ini ditekankan kesadaran masyarakat untuk mematuhi protokol Covid19 untuk mengurangi penyebaran penularan virus. Sehingga masyarakat di Kecamatan Pedurungan dapat mencegah dan memutus rantai penularan Covid19.

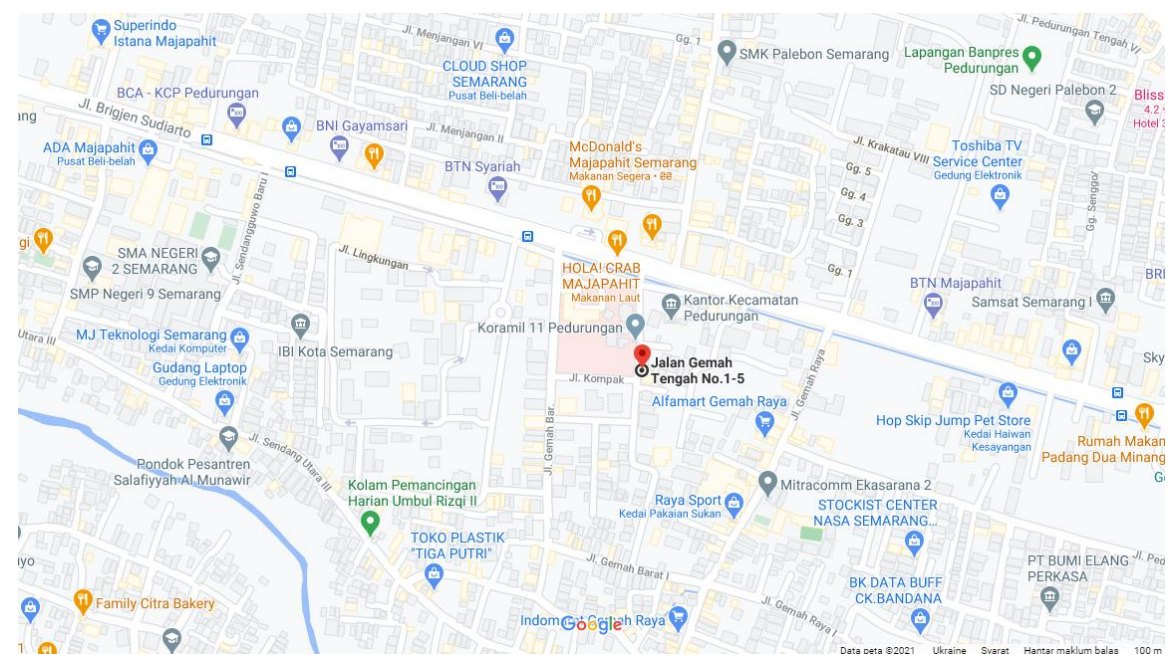

Gambar 2.1 Kecamatan Pedurungan

\section{METODE}

a. Tahap persiapan dari kegiatan adalah pembuatan pre-planning, mengajuakan izin dan persiapan tempat dan alat-alat lainnya disiapkan. Pembuatan brousur dimulai 3 hari sebelum kegiatan penyuluhan dimulai.

b. Tahap pelaksanaan acara ini dimulai dengan Penyuluhan pada Masyarakat yang diselenggarakan pada tanggal 1 s/d 2 Februari 2021 ini dilaksanakan dalam bentuk sosialisasi penggunaan masker sekaligus membagikan masker secara gratis sebanyak 200 masker kepada Masyarakat di Kecamatan Pedurungan Kota Semarang. Adapun metode yang digunakan dalam pelaksanaan penyuluhan ini adalah melalui edukasi kepada masyarakat untuk menghimbau pentingnya menggunakan masker. 
c. Evaluasi

1) Pengamatan yang dilakukan jika dijumpai masyarakat yang tidak menggunakan masker maka akan di beri edukasi dan pemberian masker gratis

2) Proses pelaksanaan kegiatan dimulai pada pukul 09:00 s/d selesai WIB.

3) Hasil

1. Masyarakt dapat memahami dan mengerti tentang pengertian covid

2. Masyarakat dapat memahami dan mengerti tentang cara penularan covid

3. Masyarakat dapat memahami dan mengerti tentang gejala covid

4. Masyarakat dapat memahami dan mengerti tentang cara pencegahan covid

\section{HASIL DAN PEMBAHASAN}

Pedurungan adalah sebuah kecamatan yang ada di Kota Semarang, Indonesia. Kecamatan Pedurungan memiliki 12 Kelurahan yang meliputi Kelurahan Gemah, Pedurungan Kidul, Plamongansari, Penggaron Kidul, Pedurungan Lor, Tlogomulyo, Pedurungan Tengah, Palebon, Kalicari, Tlogosari Kulon, Tlogosari Wetan.

Kegiatan penyuluhan pencegahan Covid-19 yang dilakukan di wilyah Kecamatan Pedurungan Kota Semarang dimulai terlebih dahulu dengan melakukan pembagian masker. Sebanyak 200 masker medis dibagikan kepada masyarakat di Kecamatan Pedurungan Kota Semarang, minimal satu orang punya dua masker yang bisa dipakai bergantian setiap hari. Produk masker medis yang dibagikan sepenuhnya buatan pelaku UKM untuk mengurangi permintaan pasar terhadap masker kain satu lapis dan menambah peluang penghasilan bagi produsen.

Selanjutnya masyarakat yang tidak menggunakan masker diberikan edukasi langsung untuk mengenakan masker kain atau masker medis, kemudian menghimbau kepada seluruh masyarakat untuk lawan Covid-19 dengan tetap mengikuti protokoler kesehatan dengan cara sering mencuci tangan menggunakan sabun. Jaga jarak dan jaga kebersihan lingkungan, khususnya pedagang kecil (mikro) yang sebagian besar tidak bisa menerapkan social distancing karena mereka harus mencari nafkah dijalan maupun dipasar, sementara protokol covid-19 juga harus dipenuhi.

Berdasarkan hasil wawancara yang dilakukan terhadap masyarakat di Kecamatan Pedurungan Kota Semarang, ternyata 70\% masyarakat sudah paham tentang pentingnya penggunaan masker, dibuktikan dengan sudah banyak banyaknya masyarakat yang menggunakan masker.

Evaluasi pelaksanaan penyuluhan dilakukan sebelum dan setelah intervensi menggunakan Pengamatan yang menunjukan terjadi peningkatan penggunaan masker yaitu subjek dengan sebelumnya $70 \%$ meningkat menjadi $80 \%$. Teknik penyuluhan ini dianggap baik untuk meningkatkan pengetahuan Masyarakat.

Berikut gambar pelaksanaan penyuluhan: 

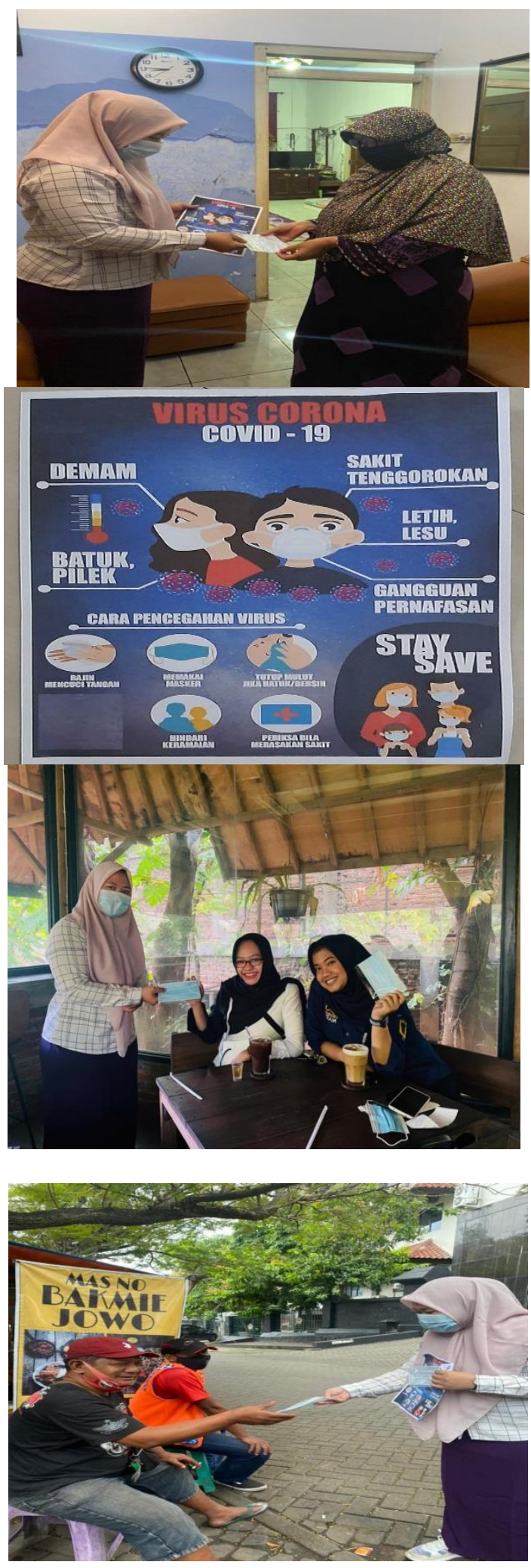


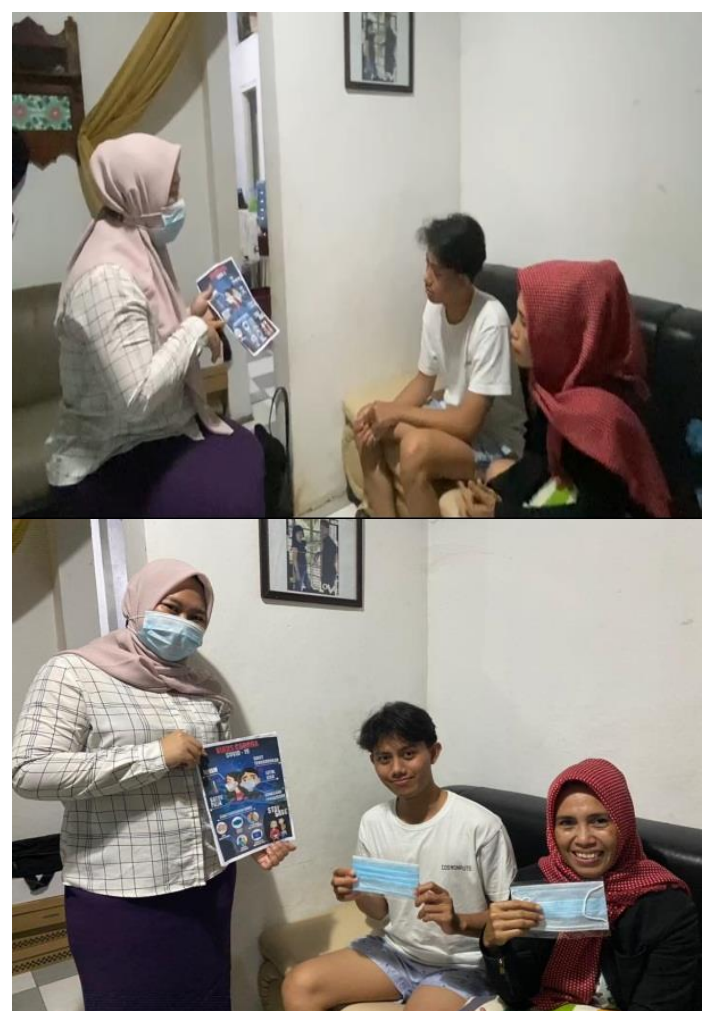

Gambar 4.1 Pelaksanaan Kegiatan Penyuluhan

\section{KESIMPULAN}

Berdasarkan hasil pelaksanaan kegiatan yang telah dilakukan, dapat ditarik beberapa kesimpulan sebagai berikut;

1. Sebelum dilaksanakanannya kegiatan sosialisasi di Kecamatan Pedurungan Kota Semarang dan pemahaman masyarakat tentang pentingnya penggunaan masker dalam mencegah Covid-19 masih kurang, dan masih banyak masyarakat yang tidak menggunakan masker.

2. Setelah dilaksanakanannya kegiatan sosialisasi di Kecamatan Pedurungan Kota Semarang, Masyarakat sudah mulai sadar pentingnya penggunaan masker.

3. Kegiatan pengabdian yang dilakukan merupakan sebuah kegiatan positif yang bertujuan menghimbau seluruh Masyarakat untuk lawan Covid-19 dengan tetap ikuti protokoler kesehatan guna rmemutus mata rantai penyebaran virus Corona. 


\section{DAFTAR PUSTAKA}

Ausrianti, R., Andayani, R. P., Surya, D. O., \& Suryani, U. (2020). Edukasi Pencegahan Penularan Covid 19 serta Dukungan Kesehatan Jiwa dan Psikososial pada Pengemudi Ojek Online. Jurnal Peduli Masyarakat, 2(2), 59 64.https: / / siagacorona.semarangkota.go.id/.

Isnainy, U. C. A. S., Zainaro, M. A., Novikasari, L., Ariyanti, L., \& Furqoni, P. D. (2020). Pendidikan Kesehatan Tentang Perilaku Hidup Bersih Dan Sehat (Phbs) Di Sma Negeri 13 Bandar Lampung. Jurnal Kreativitas Pengabdian Kepada Masyarakat (PKM), 3(1), 27-33.

Kementerian Kesehatan RI. (2020). Pedoman Kesiapsiagaan Menghadapi Infeksi Novel Coronavirus (2019-nCoV). Jakarta: Kementerian Kesehatan RI.

Naziah, N., Nuraini, N., \& Zainaro, M. A. (2018). Pengaruh Pendidikan Kesehatan Dengan Media Booklet Tentang Pencegahan Primer \& Sekunder Terhadap Pengetahuan Pasien Coronary Artery Disease (Cad) Di Klinik Sehat Natural Ciledug Tangerang Selatan TahuN 2016. Holistik Jurnal Kesehatan, 12(1), 1020.

Wahyudi, W. T., Zainaro, M. A., \& Kurniawan, M. (2021). Hubungan Paparan Asap Rokok Dengan Kejadian Ispa Pada Balita Di Wilayah Kerja Puskesmas Bandar Agung Kecamatan Terusan Nunyai Kabupaten Lampung Tengah. Malahayati Nursing Journal, 3(1), 82-91.

Wati, E., Febrianto, H., Marlia, L., Hermawan, D., Isnainy, U. C. A. S., Zainaro, M. A., \& Wandini, R. (2020). Pendidikan Kesehatan Tentang Kompres Hangat Untuk Demam Di Margorejo Dusun 6 Kecamatan Jati Agung Lampung Selatan. JURNAL KREATIVITAS PENGABDIAN KEPADA MASYARAKAT (PKM), 3(2), 395400.

World Health Organization. (2020). Anjuran mengenai penggunaan masker dalam konteks covid-19 ancaman krisis ekonomi global dari dampak penyebaran virus corona (covid-19) World Health Organization. (2020). Novel coronavirus (2019-nCoV). Situation report, 28.

Zainaro, M. A., \& Laila, S. A. (2020). Hubungan Motivasi Dan Sikap Dengan Kepatuhan Perawat Dalam Pelaksanaan Hand Hygiene Di Ruang Rawat Inap Rsud Dr. A. Dadi Tjokrodipo Kota Bandar Lampung. Malahayati Nursing Journal, 2(1), 6882. 